\title{
PENGARUH METODE KOOPERATIF DAN KOMANDO TERHADAP KETERAMPILAN TEKNIK DASAR BERMAIN SEPAKBOLA
}

\author{
Novri Gazali \\ Universitas Islam Riau \\ novri.gazali@edu.uir.ac.id
}

\begin{abstract}
ABSTRAK
Tujuan penelitian ini adalah mengungkap pengaruh metode kooperatif dan metode komando terhadap keterampilan teknik dasar bermain sepakbola. Jenis penelitian ini adalah eksperimen semu (Quasy Eksperiment), populasi penelitian ini adalah siswa putra SD Negeri 021 Kecamatan Kuantan Tengah Kabupaten Kuansing Provinsi Riau yang berjumlah 42 orang, sedangkan sampel dalam penelitian ini adalah 28 orang siswa setelah menggunakan teknik purposive sampling. Instrumen penelitian yang digunakan adalah tes keterampilan sepakbola usia 10 - 12 tahun, data dianalisis menggunakan statistik uji normalitas dan uji-t. Hasil analisis penelitian menunjukkan bahwa: (1) Terdapat pengaruh metode kooperatif yang signifikan terhadap keterampilan teknik dasar bermain sepakbola, dari rata-rata (mean) 366,07 pada tes awal menjadi 390,36 pada tes akhir, dengan beda mean $24,29\left(t_{\text {hitung }}=10,29>t_{\text {tabel }}=1,771\right)$, (2) Terdapat pengaruh metode komando yang signifikan terhadap keterampilan teknik dasar bermain sepakbola, dari rata-rata (mean) 363,36 pada tes awal menjadi 376,79 pada tes akhir, dengan beda mean 16,43 ( $\mathrm{t}_{\text {hitung }}=5,15>\mathrm{t}_{\text {tabel }}=1.771$ ), (3) Metode kooperatif lebih efektif dari pada metode komando dalam meningkatkan keterampilan teknik dasar bermain sepakbola. Rata-rata peningkatan keterampilan teknik dasar bermain sepakbola dengan menggunakan metode kooperatif adalah 24,29, sementara peningkatan keterampilan teknik dasar bermain sepakbola dengan menggunakan metode komando hanya 16,43, dengan beda mean sebesar 7,86 $\left(\mathrm{t}_{\text {hitung }}=2,64>\mathrm{t}_{\text {tabel }}=1,771\right)$.
\end{abstract}

Kata Kunci: Metode Kooperatif, Metode Komando, Keterampilan Teknik Dasar Bermain Sepakbola

\section{PENDAHULUAN}

Pada abad modern ini banyak orang yang memahami pentingnya melakukan olahraga. Mereka melakukan kegiatan olahraga dengan berbagai alasan, di antaranya untuk kesehatan, rekreasi, prestasi dan pendidikan. Olahraga merupakan perluasan dari bermain, oleh karena itu, olahraga berlandaskan pada bermain dan nilai inti dalam kegiatan itu. Pada dasarnya setiap orang melakukan olahraga untuk meningkatkan kemampuan fungsi tubuhnya yang dilakukan dengan teratur dan terencana, namun tujuan dari melakukan olahraga bergantung pada individu yang melakukannya. Olahraga mempunyai sifat dan tujuannya masing-masing, dalam olahraga prestasi terdapat beberapa aspek pendukung yang harus dimiliki setiap pemain agar berprestasi dengan baik, aspek pendukung tersebut di antaranya: kemampuan teknik, kondisi fisik, taktik dan strategi, serta aspek mental dan psikologis.

Penelitian di bidang keolahragaan merupakan salah satu usaha untuk meningkatkan mutu keolahragaan di Indonesia. Hal ini telah dilaksanakan di perguruan tinggi, namun demikian terlalu sedikit informasi perkembangan dengan penelitian 
tersebut, sehingga perkembangan prestasi olahraga di Indonesia kurang cepat, dan gejala ini nampak pula pada perkembangan olahraga di sekolah.

Saat ini pendidikan jasmani dan olahraga kesehatan khususnya di sekolah dilaksanakan dalam dua bentuk program kegiatan. Pertama kegiatan wajib atau kurikuler yaitu pendidikan olahraga yang dilaksanakan pada jam-jam sekolah. Kedua adalah program kegiatan olahraga ekstrakurikuler berupa kegiatan pendidikan olahraga bagi pelajar-pelajar yang dalam salah satu cabang olahraga, dan kegiatan ini dilakukan pada luar jam pelajaran.

Sesuai dengan tujuan kurikulum pendidikan jasmani, dalam hal ini guru pendidikan jasmani di sekolah perlu dibekali dengan pengetahuan, pengalaman, dan keterampilan yang memadai. Guru bidang studi pendidikan jasmani di sekolah harus mampu memilih metode yang cocok dan tepat, supaya tujuan pembelajaran dapat tercapai sesuai dengan yang diharapkan. Salah satu kendala yang harus dihadapi di sekolah ialah jam pelajaran yang sangat sedikit yaitu hanya satu kali pertemuan $(2 \mathrm{x} 40$ menit) dalam satu minggu.

Dari berbagai jenis olahraga di sekolah, sepakbola adalah salah satu cabang olahraga yang digemari oleh anak-anak. Untuk menggali bakat anak dan meningkatkan prestasi olahraga khususnya olahraga sepakbola dibutuhkan guru olahraga yang profesional. Guru olahraga sebagai penyusun program dan pelaksanaan kegiatan di sekolah bertanggung jawab bagi tercapainya prestasi belajar gerak yang bersifat umum bagi para siswa dan di sisi lain bertanggung jawab terhadap tercapainya prestasi olahraga berdasarkan minat dan bakat yang dimiliki siswa.

Untuk meningkatkatkan keterampilan bermain sepakbola, para siswa harus menguasai macam-macam teknik dasar sepakbola. Di dalam permainan sepakbola teknik sangat dibutuhkan, tanpa menguasai teknik sepakbola seperti passing, shooting, dribbling, heading, kontrol dengan baik, maka tujuan dari permainan, yaitu untuk mencari kemenangan akan sulit tercapai. Dalam menguasai teknik dasar bermain sepakbola, faktor kondisi fisik seperti kekuatan, daya tahan, kecepatan, kelincahan, kelentukan dan daya ledak sangat penting diajarkan kepada siswa. Jika kondisi fisik siswa kurang baik, maka cenderung tidak akan belangsung lama dalam pertandingan, karena akan mengalami kelelahan sehingga akan mengganggu kemampuan teknik. Dukungan dari unsur-unsur kondisi fisik yang baik, dapat memberikan kemampuan gerak lebih baik pula.

SD Negeri 021 Kecamatan Kuantan Tengah, merupakan salah satu lembaga pendidikan resmi yang memiliki peranan dalam membina dan mengembangkan olahraga sepakbola di Kabupaten Kuansing Provinsi Riau. Salah satu upaya yang dapat dilakukan SD Negeri 021 Kecamatan Kuantan Tengah adalah mengajarkan dan mengembangkan teknik dasar pada siswa melalui mata pelajaran pendidikan jasmani maupun melalui kegiatan ekstrakurikuler di sekolah. Pentingnya penguasaan teknik dasar bermain sepakbola di Sekolah Dasar sebagai gambaran tingkat kemampuan dan keterampilan yang dimiliki adalah untuk menghadapi Olimpiade Olahraga SIswa Nasional (O2SN) khususnya pada cabang sepakbola. Agar dapat menguasai keterampilan teknik dasar bermain sepakbola, siswa harus berlatih dengan benar dan kontinyu terhadap semua faktor yang menentukan atau mempengaruhi penguasaan keterampilan teknik dasar bermain sepakbola tesebut.

Prestasi SD Negeri 021 Kecamatan Kuantan Tengah yang didapatkan melalui kegiatan ekstrakurikuler sepakbola tiga tahun yang lalu cukup menjanjikan, karena siswa SD Negeri 021 Kecamatan Kuantan Tengah meraih juara dua O2SN cabang 
sepakbola pada tahun 2012. Akan tetapi pada tahun 2013 dan 2014 mengalami penurunan prestasi dan tidak mendapatkan gelar apapun, ini disebabkan karena teknik dasar sepakbola pada siswa SD Negeri 021 Kecamatan Kuantan Tengah masih kurang baik.

Hal ini dapat diketahui dari pengamatan peneliti saat siswa melakukan latihan masih terdapat kesalahan-kesalahan dalam pelaksanaan teknik dasar sepakbola. Kesalahan ini seperti saat siswa melakukan passing atau mengoper bola sering tidak tepat ke sasaran atau mengarah ke temannya, sedangkan pada saat mengontrol bola atau memberhentikan bola dengan kaki atau dada, bola yang dikontrol selalu lepas dan mudah direbut lawan. Begitu juga pada saat dribbling atau menggiring bola terlihat kurang baik, dan pada saat menyundul bola terlihat siswa sedikit kaku, selanjutnya pada saat melakukan shooting atau menendang bola banyak kesalahan teknik yang terlihat misalnya pada saat menendang masih ada yang menggunakan ujung kaki dan pada saat menendang ke gawang sering tidak mengarah ke gawang.

Hal ini harus menjadi perhatian dari pelatih atau guru ekstrakurikuler. Pelatih harus mengetahui kenapa siswa tidak mampu menguasai keterampilan teknik dasar dengan baik. Banyak faktor yang mempengaruhi seperti kondisi fisik yang belum begitu baik, ketersediaan sarana dan prasarana kurang memadai, motivasi siswa dalam menjalani proses latihan, minat dan bakat yang belum tersalurkan dengan baik. Semua faktor yang dikemukakan ini dapat menentukan keberhasilan seseorang dalam mempelajari dan menguasai suatu bentuk keterampilan teknik dasar bermain sepakbola.

Di samping faktor-faktor yang telah diuraikan di atas, rendahnya keterampilan teknik dasar bermain sepakbola disebabkan karena guru pendidikan jasmani tidak memiliki program latihan yang terstruktur dan sangat kurang diberi pelatihan atau penataran baik dalam bidang pengembangan metode mengajar maupun tentang pelaksanaan bermain sepakbola. Hal ini mengakibatkan guru pendidikan jasmani di sekolah kurang menerima informasi yang baru khususnya teknik dasar sepakbola.

Metode pembelajaran yang dilakukan oleh guru dalam praktek pembelajaran pendidikan jasmani umumnya dan permainan sepakbola khususnya, cenderung berpusat pada guru, dimana para siswa melakukan latihan fisik atau latihan keterampilan teknik dasar berdasarkan perintah dari guru. Masih banyak guru-guru pendidikan jasmani ketika mengajar mempergunakan pendekatan atau metode konvensional yang paling disenangi dalam pelaksanaan proses pembelajaran di sekolah. Metode pembelajaran yang monoton membuat siswa merasa jenuh dan bosan dalam mengikuti proses pembelajaran.

Pemilihan metode pembelajaran yang tepat sangat berhubungan dengan situasi belajar. Pertimbangan penggunaan metode pembelajaran tertentu harus memperhatikan dalam kondisi bagaimana dan dimana proses pembelajaran tersebut dilaksanakan. Kondisi belajar juga berhubungan dengan karakteristik dari materi pelajaran. Dengan demikian karakteristik dari materi pelajaran juga harus dipertimbangkan dalam memilih metode pembelajaran. Jadi untuk mengatasi masalah pembelajaran tersebut dan untuk meningkatkan keterampilan teknik dasar bermain sepakbola, maka guru perlu memperbaiki dan meningkatkan kualitas praktek pembelajaran secara berkesinambungan sehingga meningkatkan mutu hasil pembelajaran serta meningkatkan efisiensi pengelolaan pembelajaran. Metode yang digunakan untuk mengatasi masalah pembelajaran sepakbola tersebut adalah metode kooperatif dan komando. 
Metode pembelajaran kooperatif (cooperative learning) adalah metode pembelajaran yang memberikan kesempatan kepada siswa untuk bekerja sama antara sesama siswa dalam menyelesaikan kompetensi pembelajaran penjas. Metode pembelajaran kooperatif sangat penting dilakukan guna menunjang keterampilan siswa dalam permainan sepakbola. Keunggulan metode kooperatif dalam pembelajaran keterampilan teknik dasar bermain sepakbola adalah : (1) siswa lebih leluasa mengembangkan keterampilan teknik dasar bermain sepakbola berdasarkan potensi yang dimilikinya, (2) siswa dapat belajar keterampilan teknik dasar bermain sepakbola dari teman sekelompok, (3) pemanfaatan waktu belajar keterampilan teknik dasar bermain sepakbola lebih efektif dalam penggunaan waktu pelajaran, (4) siswa tidak terlalu lama menunggu giliran untuk melakukan latihan.

Pembelajaran kooperatif merupakan salah satu metode pembelajaran yang terstruktur dan sistematis, dimana kelompok-kelompok kecil bekerja sama untuk mencapai tujuan-tujuan bersama. Menurut Cooper dan Henich dalam Asma (2012:2) menjelaskan bahwa pembelajaran kooperatif sebagai metode pembelajaran yang melibatkan kelompok-kelompok kecil yang heterogen dan siswa bekerja sama untuk mencapai tujuan-tujuan dan tugas-tugas akademik bersama, sambil bekerja sama belajar keterampilan-keterampilan koloboratif dan sosial. Anggota-anggota kelompok memiliki tanggung jawab dan saling bergantung satu sama lain untuk mencapai tujuan bersama. Pembelajaran kooperatif (cooperative learning) menurut Slavin (2005:8) merujuk berbagai macam model pembelajaran dimana para siswa bekerja sama dalam kelompok-kelompok kecil yang terdiri dari berbagai tingkat prestasi, jenis kelamin, dan latar belakang etnik yang berbeda untuk saling membantu, saling mendiskusikan,dan beragumentasi untuk mengasah pengetahuan yang mereka kuasai saat itu dan menutup kesenjangan dalam pemahaman masing-masing.

Cooperative learning merupakan suatu sikap atau perilaku bersama dalam bekerja, dalam struktur kerja sangat dipengaruhi oleh keterlibatan dari setiap anggota kelompok itu sendiri. Pada pembelajaran kooperatif, interaksi ditandai dengan tujuan saling tergantung dengan individu yang lain. Kelompok kooperatif mempunyai rasa tanggung jawab pribadi. Ini berarti semua siswa perlu mengetahui materi yang sedang digarap dan memberikan kontribusi agar seluruh kelompok berhasil.

Metode komando adalah metode yang keseluruhan isi latihan ditentukan oleh guru atau pelatih. Siswa atau atlet hanya menirukan dan melaksanakan semua perintah dan aturan guru atau pelatih. Menurut Mosston (1994:65) "metode pembelajaran komando adalah metode pendekatan ditandai oleh guru yang membuat semua keputusan tentang bentuk, tempo, urutan, intensitas,penilaian dan penetapan tujuan untuk setiap tahap pembelajaran, sedangkan siswa merespon semua keputusan guru tersebut". Sehingga dapat dikatakan bahwa semua keputusan guru sama dengan keputusan siswa. Paturusi (2012:123) "menjelaskan metode komando adalah pendekatan mengajar yang paling bergantung pada guru". Guru menyiapkan semua aspek pengajaran, guru sepenuhnya bertanggung jawab dan berinisiatif terhadap pengajaran dan memantau kemajuan belajar.

Menurut Husdarta dan Saputra (http://www.slideshare.net) mengemukakan bahwa:

Metode ini bertujuan mengarahkan siswa dalam melakukan tugas gerak secara akurat dan di dalam waktu yang singkat. Siswa harus mengikuti segala instruksi yang disampaikan oleh guru. Dalam metode komando peran guru sangat dominan, yaitu: (a) Membuat segala keputusan dalam pembelajaran, (b) 
Membuat segala keputusan yang terkait dengan : mata pelajaran, susunan pelaksanaan tugas, memulai dan mengakhiri waktu pelaksanaan pengajaran, interval, dan mengklarifikasi berbagai pertanyaan siswa, (c) Memberi umpan balik kepada siswa mengenai peran guru dan materi, adapun peran siswa adalah hanya mengikuti dan melakukan tugas yang diinstruksikan guru.

Menurut pemaparan di atas dapat diartikan bahwa metode komando merupakan peranan guru lebih dominan dibandingkan siswa, tujuan metode mengajar ini adalah siswa bisa belajar dengan cepat. Jadi semua proses pengajaran dikendalikan oleh guru, siswa hanya menuruti instruksi saja, tidak diberi kesempatan untuk berfikir dan berkreatifitas. namun penerapan metode ini siswa bisa belajar cepat dalam menguasai teknik serta waktupun lebih efisien.

Melihat kenyataan ini maka penulis berkeinginan melakukan suatu penelitian tentang keterampilan teknik dasar bermain sepakbola siswa SD Negeri 021 Kecamatan Kuantan Tengah Kabupaten Kuansing Provinsi Riau dan berusaha untuk mencari solusi dengan melakukan penelitian eksperimen yaitu dengan memberi perlakuan terhadap siswa yang mengambil kegiatan ekstrakurikuler sepakbola dengan memberikan dua metode yaitu metode kooperatif dan komando.

\section{METODE PENELITIAN}

Penelitian ini menggunakan jenis penelitian eksperimen semu (quasi eksperiment) dengan tujuan penelitian ini untuk melihat pengaruh metode kooperatif dan metode komando terhadap keterampilan teknik dasar bermain sepakbola.

Sebelum perlakuan (treatment) dilaksanakan, terlebih dahulu diberikan pre-test kepada sampel. Pre-test ini bertujuan untuk memperoleh data awal tentang keterampilan bermain sepakbola yang dimiliki oleh siswa. Setelah pre-test maka sampel dibagi menjadi dua kelompok dengan dengan cara ordinary matched pairing agar kedua sampel ini tergolong homogen. Selanjutnya dilakukan undian untuk menentukan kelompok mana yang diberikan perlakuan menggunakan metode kooperatif dan kelompok yang diberi perlakuan menggunakan metode komando.

populasi penelitian ini adalah seluruh siswa SD Negeri 021 Kecamatan Kuantan Tengah Kabupaten Kuansing Provinsi Riau yang berumur 10 - 12 tahun yang mengikuti kegiatan ekstrakurikuler sepakbola sebanyak 42 orang. Sampel yang digunakan bersifat homogen karena hanya laki-laki saja sebagai objek yang diteliti. Teknik pengambilan sampel dalam penelitian ini menggunakan purposive sampling yaitu teknik penentuan sampel dengan pertimbangan tertentu, sehingga sampel dalam penelitian ini adalah siswa putra kelas IV dan V yang berusia 10 - 12 tahun yang mengikuti kegiatan ekstrakurikuler sepakbola sebanyak 28 orang.

Instrumen penelitian yang digunakan dalam penelitian ini adalah tes keterampilan sepakbola usia 10-12 tahun (pusat pengembangan kualitas jasmani, 2009:9). Tes ini bertujuan untuk mengetahui keterampilan teknik dasar bermain sepakbola yang terdiri dari: dribbling (menggiring bola), passing (mengoper bola), shooting (menendang bola), heading (menyundul bola), running (berlari mengenai bola), throw in (lemparan ke dalam).

Data yang diperoleh nanti akan diolah dengan "uji t". Sebelum data diolah terlebih dahulu dilakukan uji persyaratan analisis, yaitu uji normalitas menggunakan Uji Liliefors dengan taraf signifikansi $\alpha=0,05$. 


\section{HASIL DAN PEMBAHASAN}

Berdasarkan hasil perhitungan uji normalitas ke empat kelompok rancangan penelitian di atas ditemukan bahwa harga $\mathrm{L}_{\text {obesrvasi }}\left(\mathrm{L}_{\mathrm{o}}\right)$ yang diperoleh lebih kecil dari harga $\mathrm{L}_{\text {tabel }}$ pada taraf nyata 0,05 . Dengan demikian dapat disimpulkan bahwa semua kelompok data pada penelitian ini diambil dari populasi yang berdistribusi normal sehingga dapat digunakan pengujian hipotesis penelitian.

Pengujian Hipotesis penelitian ini dilakukan dengan uji t. Penggunaan uji t ini bertujuan untuk mengetahui pengaruh variabel bebas terhadap variabel terikat. Pengaruh utama dalam penelitian ini adalah; (1) Pengaruh metode kooperatif terhadap keterampilan teknik dasar bermain sepakbola siswa, (2) Pengaruh metode komando terhadap keterampilan teknik dasar bermain sepakbola siswa, (3) Efektifitas antara metode kooperatif dengan metode komando terhadap keterampilan teknik dasar bermain sepakbola siswa.

Berdasarkan rangkuman hasil perhitungan di atas dapat dikemukakan bahwa: (1) Hipotesis alternatif $\left(\mathrm{H}_{\mathrm{a}}\right)$ yang menyatakan bahwa metode kooperatif berpengaruh secara signifikan terhadap keterampilan teknik dasar bermain sepakbola siswa karena $\mathrm{t}_{\text {hitung }}=10.29>\mathrm{t}_{\text {tabel }}=1.771$, (2) Hipotesis alternatif $\left(\mathrm{H}_{\mathrm{a}}\right)$ yang menyatakan bahwa metode komando berpengaruh secara signifikan terhadap keterampilan teknik dasar bermain sepakbola siswa karena $t_{\text {hitung }}=5.15>t_{\text {tabel }}=1.771$, (3) Hipotesis alternatif $\left(\mathrm{H}_{\mathrm{a}}\right)$ yang menyatakan bahwa metode kooperatif lebih efektif daripada metode komando terhadap keterampilan teknik dasar bermain sepakbola siswa $t_{\text {hitung }}=2.64>t_{\text {tabel }}=$ 1.771 .

Berdasarkan analisis data hipotesis penelitian pertama menunjukkan bahwa metode kooperatif berpengaruh terhadap keterampilan teknik dasar bermain sepakbola siswa. Rata-rata skor tes awal yaitu 366.07, sedangkan untuk nilai rata-rata skor tes akhir adalah 390.36. Terjadinya peningkatan keterampilan teknik dasar bermain sepakbola siswa ini berkemungkinan disebabkan oleh adaptasi fisik dari latihan metode kooperatif yang diproses latihannya dilakukan secara berkelompok dengan menggabungkan siswa yang mempunyai keterampilan teknik dasar bermain sepakbola yang baik dengan siswa yang mempunyai keterampilan teknik dasar bermain sepakbola yang kurang baik. Sehingga dari latihan yang diberikan dapat mempengaruhi keterampilan teknik dasar bermain sepakbola siswa.

Berdasarkan analisis data hipotesis penelitian kedua menunjukkan bahwa metode komando berpengaruh terhadap keterampilan teknik dasar bermain sepakbola siswa. Rata-rata skor tes awal yaitu 363.36, sedangkan untuk nilai rata-rata skor tes akhir adalah 379.79. Terjadinya peningkatan keterampilan teknik dasar bermain sepakbola siswa ini berkemungkinan disebabkan oleh karena metode komando membuat siswa dapat menerima materi dengan mudah, mempraktekan dan memahami yang diberikan oleh guru sehingga apa yang diinginkan oleh guru tercapai

Berdasarkan analisis data hipotesis penelitian ketiga menunjukkan bahwa efektifitas antara metode kooperatif dengan komando terhadap keterampilan teknik dasar bermain sepakbola siswa. Hal ini dapat dilihat peningkatan nilai rata-rata yaitu metode kooperatif adalah sebesar 24.29, sementara metode komando sebesar 16.43. Dengan demikian dapat dikatakan bahwa lebih baik dan lebih efektif latihan metode kooperatif diberikan dalam meningkatkan keterampilan teknik dasar bermain sepakbola. 


\section{KESIMPULAN}

Berdasarkan hasil analisis data yang telah dikemukakan terdahulu, maka dapat diambil beberapa kesimpulan yaitu :

1. Terdapat pengaruh metode kooperatif yang signifikan terhadap keterampilan teknik dasar bermain sepakbola siswa SD Negeri 021 Kecamatan Kuantan Tengah Kabupaten Kuansing Provinsi Riau, dari rata-rata (mean) 366.07 pada tes awal menjadi 390.36 pada tes akhir, dengan beda mean $24.29\left(t_{\text {hitung }}=10.29>t_{\text {tabel }}=\right.$ 1.771).

2. Terdapat pengaruh metode komando yang signifikan terhadap keterampilan teknik dasar bermain sepakbola siswa SD Negeri 021 Kecamatan Kuantan Tengah Kabupaten Kuansing Provinsi Riau, dari rata-rata (mean) 363.36 pada tes awal menjadi 376.79 pada tes akhir, dengan beda mean $16.43\left(\mathrm{t}_{\text {hitung }}=5.15>\mathrm{t}_{\text {tabel }}=\right.$ 1.771).

3. Metode kooperatif lebih efektif dari pada metode komando dalam meningkatkan keterampilan teknik dasar bermain sepakbola siswa SD Negeri 021 Kecamatan Kuantan Tengah Kabupaten Kuansing Provinsi Riau. Rata-rata peningkatan keterampilan teknik dasar bermain sepakbola dengan menggunakan metode kooperatif adalah 24.29, sementara peningkatan keterampilan teknik dasar bermain sepakbola dengan menggunakan metode komando hanya 16.43, dengan beda mean sebesar $7.86\left(t_{\text {hitung }}=2.64>t_{\text {tabel }}=1.771\right)$.

\section{DAFTAR PUSTAKA}

Asma, Nur. (2012). Model Pembelajaran Kooperatif. Padang: UNP Press.

http://www.slideshare.net. Akses 20 November 2013

Mosston, Muska. (2008). Teaching Physical Education. New York: Mc Millan College Publishing.

Paturusi, Achmad. (2012). Manajemen Pendidikan Jasmani dan Olahraga. Jakarta: Rieneka Cipta.

Pusat Pengembangan Kualitas Jasmani. (2009). Tes Keterampilan Sepakbola. Jakarta: Departemen Pendidikan Nasional.

Slavin, E Robert. (2005). Cooperative Learning. Bandung: Alfabeta. 